\title{
MONTHLY
} WEATHER REVIEW

Editor, JAMES E. CASKEY, JR.

Volume 81

Number 2

FEBRUARY 1953

Closed April 15, 1953
Issued May 15, 1953

\section{ANALYSIS OF WINDS, WIND WAVES, AND SWELL OVER THE SEA TO THE EAST OF JAPAN DURING THE TYPHOON OF SEPTEMBER 26, 1935}

\author{
H. ARAKAWA AND K. SUDA \\ Meteorological Research Institute and Hydrographic Department, Tokyo \\ [Manuscript received April 29, 1952; revision received October 21, 1952] \\ ABSTRACT
}

\begin{abstract}
An analysis of winds, wind waves, and swell over the sea to the east of Japan during the historical typhoon of September 26, 1935, is given. Occurrence of the storm and its movement across a main squadron of the Imperial Japanese Fleet which was then conducting grand maneuvers provided what may be the best coverage on record of surface winds, wind waves, and swell within 200 nautical miles of a typhoon center in its mature stage, and furnished an unequaled set of data for studying the relation between the meteorological and oceanographical elements over the ocean during a period of hurricane winds.
\end{abstract}

\section{INTRODUCTION}

For a number of years, the Hydrographic Department, Imperial Japanese Navy, kept secret the meteorological observations $[1,2,3]$ on winds, wind waves, and swell over the sea to the east of Japan during the historical typhoon of September 26, 1935. The Hydrographic Department prepared a report in 1937 [1] that contained fairly good descriptions, tabulations, and a set of successive maps illustrating the pressure patterns, the field of wind speed (isovels) and lines of constant wave heights through the period 0600 to $1800 \mathrm{JMT}$ of the $26 \mathrm{th}$. The current report is intended to present pertinent extracts from this report and further intermediate studies, with the hope that they may be of assistance in establishing a firmer understanding of the dynamics of a typhoon in its mature stage.

\section{MOVEMENT OF TYPHOON ACROSS THE FLEET}

On September 16, 1935, the Central Meteorological Observatory, Tokyo, discovered evidence of a tropical disturbance in the formative stage in the sea northwest of the island of Saipan. It soon increased to typhoon force and moved slowly on a variable northerly course. The course turned more to north-northeast as the typhoon moved through western Japan on the 25th. After leaving the West Japan area, the center continued a northnortheasterly course, crossed over the Sea of Japan, and dissipated as it moved to sea to the west of Hokkaido.

$249914-53-1$
Long before the first typhoon dissipated, the next tropical disturbance developed in the sea east-northeast of Saipan on September 20. This new typhoon moved on a northwesterly course, and thence curved northward, its intensity increasing to typhoon force. At $0300 \mathrm{JMT}$, September 26, the S. S. Ogura-maru reported hurricane winds 29 to $35 \mathrm{~m}$. sec. ${ }^{-1}$ (56 to $68 \mathrm{knots}$ ) from the southeast, and falling pressure of $732.5 \mathrm{~mm}$. of $\mathrm{Hg}$. $(977 \mathrm{mb}$.) near the center. The typhoon finally moved on a northnortheasterly course at the speed of about 70 to $80 \mathrm{~km}$. $\mathrm{hr}^{-1}$ (38 to 43 knots) and passed over sea to the east of Japan in its mature stage. Thus it completed its full cycle of development in the open sea and never passed over Japan proper. Table 1 shows the central pressure, the track, and the velocity of movement of this second typhoon.

TABLE 1.-Central pressure, track, and velocity of the typhoon center, Sept. 21-27, 1935. (From the Geophysical Review for September $1935[3])$

\begin{tabular}{|c|c|c|c|c|c|}
\hline \multirow{2}{*}{$\begin{array}{l}\text { Date and hour (135th meridian } \\
\text { civil time) }\end{array}$} & \multirow{2}{*}{$\begin{array}{c}\text { Central } \\
\text { pressure } \\
\text { (esti- } \\
\text { mated) } \\
\text { mm. H. } \\
\text { (mb.) }\end{array}$} & \multicolumn{2}{|c|}{ Locus of center } & \multicolumn{2}{|c|}{ Movement of center } \\
\hline & & $\begin{array}{l}\text { Lat. } \\
\text { N. }\end{array}$ & $\begin{array}{l}\text { Long. } \\
\mathrm{E} .\end{array}$ & Direction & $\begin{array}{c}\text { Speed } \\
\text { km/ } \\
\text { bour } \\
\text { (knots) }\end{array}$ \\
\hline $\begin{array}{l}\text { Sept. } 21,06 \mathrm{~h} \\
\text { Sept. } 22,06 \mathrm{~h} \\
\text { Sept. } 23,06 \mathrm{~h} \\
\text { Bept. } 24,06 \mathrm{~h} \\
\text { Sept. } 25,06 \mathrm{~h} \\
\text { Sept. } 26,06 \mathrm{~h} \\
\text { Sept. } 27,06 \mathrm{~h}\end{array}$ & $718(957)$ & $\begin{array}{l}17 \\
17 \\
18 \\
20 \\
25 \\
36 \\
50\end{array}$ & $\begin{array}{l}150 \\
148 \\
147 \\
146 \\
144 \\
143 \\
155\end{array}$ & $\begin{array}{c}W \\
W-N W \\
N N W \\
N N W \\
N N W-N \\
N N E-N E \\
N\end{array}$ & $\begin{array}{r}7(4) \\
7(4) \\
9(5) \\
19(10) \\
46(25) \\
73(39) \\
85(46)\end{array}$ \\
\hline
\end{tabular}




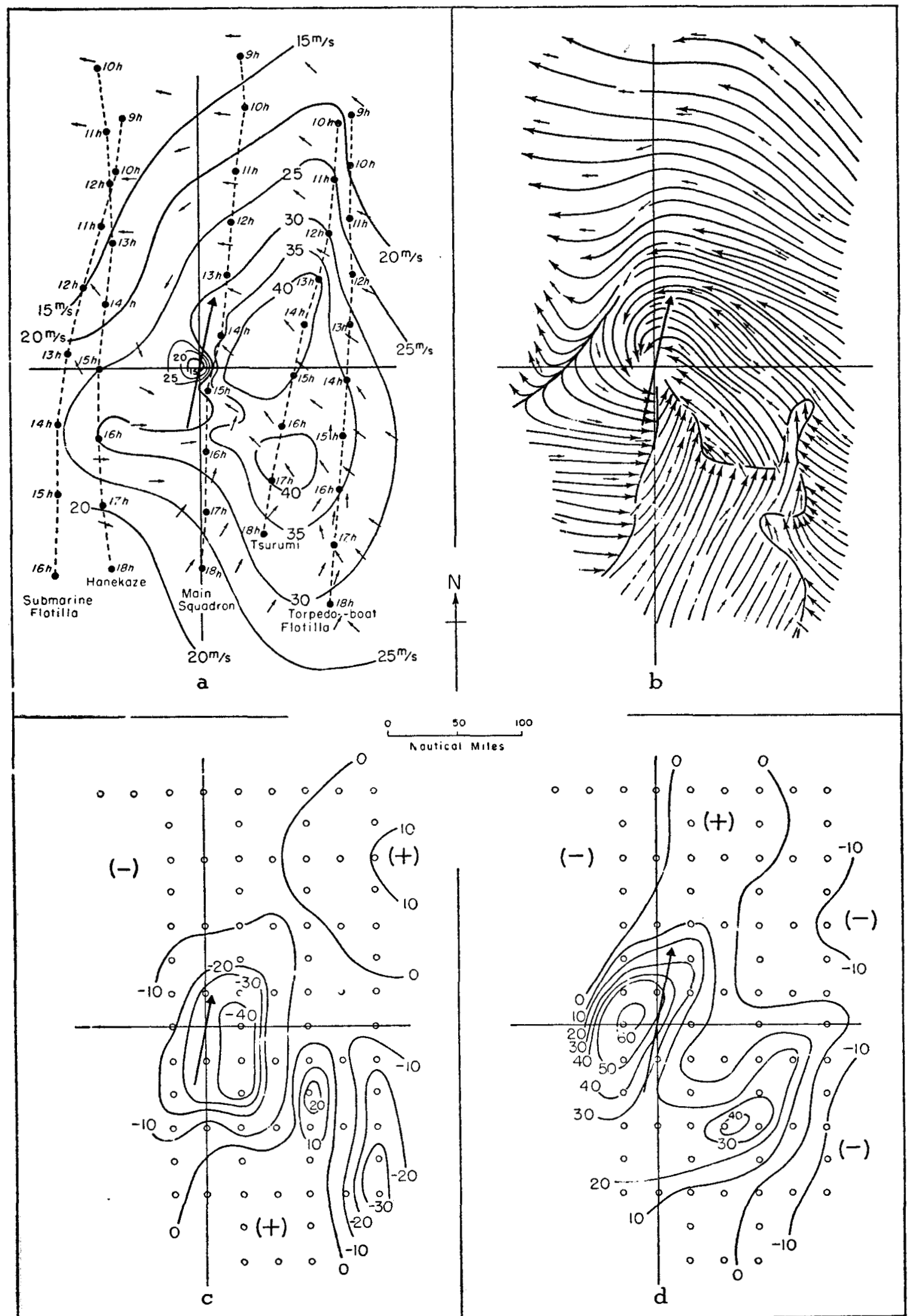

Figure 1.-Composite charts of the typhoon, September 26, 1935. Intersection of cross-lines represents the center of pressure symmetry. The beavy arrow through the center indicates the direction of movement of the typhoon. (a) Chart of wind speeds and directions in the typhoon. Small arrows represent the wind directions: isovels (lines of constant wind speeds) are drawn for each $5 \mathrm{~m}$. sec.-1 Dots are positions of naval units at hourly intervals (JMT). (b) Streamline patterns over the same area. (c) Horizontal divergence field computed from the wind field for the storm. Small circles indicate positions where computations were made. To obtain horizontal divergence, multiply the indicated values by m. sec.-1 $\times(50 \text { nantical miles })^{-1}$ or $1.1 \times 10^{-5}$ sec. $^{-1}$ (d) Vorticity field computed from the wind field for the storm. Small circles indicate positions where computations were made. To obtain vorticity, multiply the indicated values by m. sec. $-1 \times(60 \text { nautical miles })^{-1}$ or $1.1 \times 10^{-8} \mathrm{sec}^{-1}$ 
As it advanced north-northeastward, the typhoon center crossed over the RED 4th Imperial Japanese Fleet shortly after noon of September 26. Figures 2 (inset) and 6 show the path of the typhoon through the maneuverirg area. Figure 1a shows the movement of the various navul units relative to the center of the typhoon. The general path of the main squadron, the torpedo-boat flotilla, the submarine flotilla, the transport ship Tsurumi, and the destroyer Hanekaze relative to the storm shows that a fairly dense net was available to obtain successfully a good number of observations from the storm area. Occurrence of the storm and its movement across the main squadron provided what may be the best coverage on record of surface winds, wind waves, and swell within 200 nautical miles of a typhoon center. Simultaneous observations of wave height during the course of the storm furnished an unequalled set of data for relations between the meteorological and oceanographical elements over the ocean during a period of strong winds.

The observation of the second typhoon was especially noteworthy for the following three interesting features. (1) The storm kept to the open sea in a mature stage. (2) The storm center crossed over a main squadron of the Imperial Japanese Fleet ${ }^{1}$ which was then conducting grand maneuvers. (3) The net of meteorological observations was fortunately fairly dense. These observations have made it possible to construct a more complete picture of the structure of a typhoon in its mature stage than has been possible before.

\section{METEOROLOGICAL OBSERVATIONS}

When the center reached the main squadron at 1420 to $1435 \mathrm{JM}^{\prime} \mathrm{T}$, the minimum pressure was recorded as follows:

\begin{tabular}{|c|c|c|c|c|}
\hline Warship & \multicolumn{2}{|c|}{ Minimum pressure } & $\begin{array}{l}\text { Date and hour } \\
\text { meridian civi }\end{array}$ & $\begin{array}{l}r(135 t h) \\
\text { il time }\end{array}$ \\
\hline Haguro...... & 719. $3 \mathrm{mmHg}$ & $(959 \mathrm{mb})$ & Sept. 26, &, 1418 \\
\hline$H 6 \operatorname{sh} \theta \ldots$ & 722. 0 & $(963) \ldots \ldots$ & & 1420 \\
\hline yo _......... & 718. 2 & $(958) \ldots \ldots$ & & 142 \\
\hline igara......... & $721.8 ?$ & $(962) \ldots \ldots$ & & 142 \\
\hline Myókô.......... & $720.5 ?$ & 1) & about & 142 \\
\hline Nachi__._. & 720.5 & - & & 1 \\
\hline$i_{\ldots \ldots} \ldots \ldots$ & & $(959)$ & & 14 \\
\hline$u m a_{\ldots} \ldots \ldots$ & 719.6 & $(959) \ldots \ldots$ & & 14 \\
\hline
\end{tabular}

The barometric readings from the mercury barometer (marine type) on the Warship Nachi were taken for every five consecutive minutes, and are considered to be most reliable. The observations of wind speeds and directions by means of cup anemometers were available for each group of the units indicated in figure 1a. The mean (over 20-minute periods) wind speeds calculated from these data are tabulated in table 2.

It must be kept in mind, however, that the progressive movement of the storm was very large (more than $70 \mathrm{~km}$ $\mathrm{hr}^{-1}$ ) and the latitude was rather high (about $40^{\circ} \mathrm{N}$.). Therefore the storm was not circular or symmetrical with

\footnotetext{
1 The bows of two destroyers, Hatsuyuki and Yagiri, were broken off as a result of excessive storm waves, and many officers and sailors were lost. Arakawa, one of the authors, was then a forecaster of the Central Meteorological Observatory, Tokyo, and was vitally concerned with this typhoon.
}

respect to its center of pressure. The "eye" was 8 to 9 nautical miles in radius. The field of winds suggests the formation of fronts in the vortex as it moved into the middle latitudes. The streamline patterns shown in figure $1 \mathrm{~b}$ exhibit a pronounced similarity to Shaw's representation of the air currents in a cyclone [4]. The horizontal divergence field and the relative vorticity field for the storm computed from the wind field are shown in figures $1 \mathrm{c}$ and $1 \mathrm{~d}$. The values for the horizontal divergence and the vorticity are in meters per second per 50 nautical miles, or $1.1 \times 10^{-5} \mathrm{sec}^{-1}$ The singularity in the eye of the storm has been disregarded in figure $1 \mathrm{c}$ in order to avoid complications. It might be pointed out that the vorticity corresponding to the Coriolis parameter at the latitude in question (about $40^{\circ} \mathrm{N}$.) has an approximate value of $0.93 \times 10^{-4}$ sec. $^{-1}$

From table 2, we can see that the wind speeds were much greater in the right half than in the left half of the typhoon.

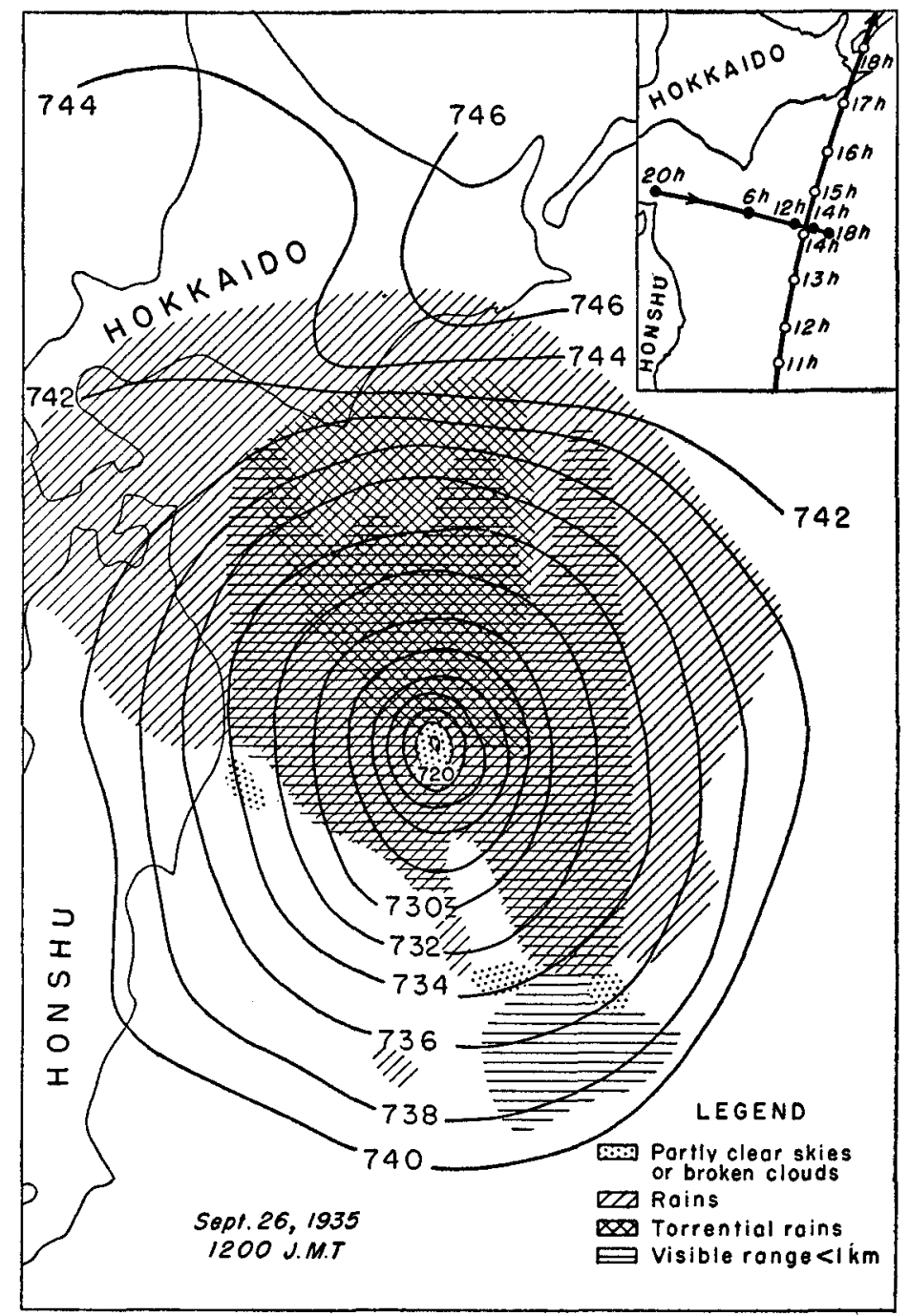

Finure 2.--Pressure pattern over the sea to the east of Japan at 1200 JMT, September 26, 1935. Isobars are arawn for each $2 \mathrm{~mm}$. of $\mathrm{Hg}$. (about $2.7 \mathrm{mb}$.). Shading indicates composite distribution of rains, torrential rains, and poor visibilities $(<1 \mathrm{~km}$.) relative to the center of the typhoon. The inset (upper right) shuws the path of the typhoon center during the critical period from 1100 to $1800 \mathrm{JMT}$, september 26 , and the trajectory traversed by the main squadron from $2000 \mathrm{JMT}$, September 25 to $1800 \mathrm{JMT}$, September 26. 
TABLE 2.-The mean (over 20 minute periods) wind speeds (m/sec.) for each group in the fleet, Sept. 26, 1935

\begin{tabular}{|c|c|c|c|c|c|c|}
\hline & Submarine flotilla & Hanekaze & \multicolumn{2}{|c|}{ Main squadron } & Tsurumi & Torpedo-boat flotilla \\
\hline Name of warships, etc.--- & $\begin{array}{l}\text { Mean values from this fio- } \\
\text { tilla. }\end{array}$ & Hanekaze.... & $\begin{array}{l}\text { Ashigara } \\
\text { Sendai } \\
\text { Taigei } \\
\text { Myoko } \\
\text { Nachi } \\
\text { Haguro } \\
\text { Mogami } \\
\text { Mikuma }\end{array}$ & $\begin{array}{l}\text { Kitakami } \\
\text { Kiso } \\
\text { Ooi } \\
\text { Tenryu } \\
\text { Ryuzyo } \\
\text { Hoshó } \\
\text { Kamui }\end{array}$ & Tsurumi...... & $\begin{array}{l}\text { Mean values from this flo- } \\
\text { tilla. }\end{array}$ \\
\hline $\begin{array}{l}06 \mathrm{~h} \\
07 \mathrm{~h} \\
08 \mathrm{~h} \\
09 \mathrm{~h} \\
10 \mathrm{~h} \\
11 \mathrm{~h} \\
12 \mathrm{~h} \\
13 \mathrm{~h} \\
14 \mathrm{~h} \\
\text { About } 14 \mathrm{~h} 30 \mathrm{~m} \\
15 \mathrm{~h} \\
16 \mathrm{~h} \\
17 \mathrm{~h} \\
18 \mathrm{~h}\end{array}$ & \begin{tabular}{|r|}
6 \\
6 \\
6 \\
9 \\
10 \\
8 \\
7 \\
10 \\
5 \\
2
\end{tabular} & \begin{tabular}{|c|}
8 \\
10 \\
10 \\
11 \\
15 \\
18 \\
25 \\
30 \\
20 \\
19
\end{tabular} & \multicolumn{2}{|c|}{$\begin{array}{r}13.5 \\
12.8 \\
12.5 \\
13.7 \\
16.4 \\
21.1 \\
25.3 \\
29.8 \\
32.5 \\
134.5 \\
31.5 \\
31.5 \\
26.3 \\
23.5\end{array}$} & $\begin{array}{l}12 \\
13 \\
17 \\
18 \\
22 \\
27 \\
30 \\
41 \\
42\end{array}$ & $\begin{array}{l}11.6 \\
14.1 \\
1 . .2 \\
17.9 \\
19.1 \\
23.7 \\
27.3 \\
32.3 \\
35.0 \\
336.0 \\
35.1 \\
32.3 \\
29.8\end{array}$ \\
\hline \multirow[t]{2}{*}{ Remarks. } & $\begin{array}{l}\text { The center passed about } 100 \\
\text { nautical miles east of this } \\
\text { flotilla. }\end{array}$ & $\begin{array}{l}\text { The center passed about } 75 \\
\text { nautical miles east of this } \\
\text { destroyer. }\end{array}$ & \multirow{2}{*}{\multicolumn{2}{|c|}{$\begin{array}{l}\text { The center moved through the } \\
\text { main squadron atabout } 1430 \\
\text { JMT. The radius of the } \\
\text { calm area with partial clear- } \\
\text { ing was approximately } 8 \\
\text { nautical miles. }\end{array}$}} & $\begin{array}{l}\text { The center passed about } 70 \\
\text { nautical miles west of this } \\
\text { destroyer. }\end{array}$ & $\begin{array}{l}\text { The center passed more than } \\
100 \text { nautieal miles west of } \\
\text { this flotilla. }\end{array}$ \\
\hline & \multicolumn{2}{|c|}{ In the left hall of the typhoon } & & & \multicolumn{2}{|c|}{ In the right balf of the typhoon } \\
\hline
\end{tabular}

1 Maximum mean.

The precipitation during the passage of the typhoon is given in figure 2 in relation to the movement of the typhoon center. This figure is a reproduction of a chart prepared by the Hydrographic Department [1]. Very little precipitation occurred in the rear half of the storm, and the greatest precipitation intensity was 0 to 180 nautical miles from the typhoon center in the direction towards which the center was advancing at the time. This is consistent with the result given by Cline [5]. At the center, the clouds became broken and faint sunlight succeeded the torrential rain. The visibilities (given in table 3) were quite poor and the horizon was limited at a distance of a few meters on account of the rain and spray in the typhoon area except in the left rear quadrant.

\section{SEA AND SWELL OBSERVATIONS}

The problem of forecasting sea and swell is one of current interest. The state of the sea and the length and height of the swell in the open sea under stormy conditions are well-known from various authorities. This section deals with the generation of wind waves defined as waves which are growing in height under the influence of wind, and of swell consisting of wind-generated waves which have advanced into regions having local winds whose direction is different from that of the wave motion.

There is little regularity in the appearance of the sea surface, particularly when a stormy wind blows. Although individual waves can be recognized and their wave heights, periods, wavelengths, and wave velocities measured, such measurements are extremely difficult and comparatively inaccurate under the condition of hurricane windss.

When waves of different wave fronts are present simultaneously, the appearance of the free surface becomes very complicated. At some points the waves are opposite in phase and therefore tend to eliminate each other, whereas at other points they coincide in phase and reinforce each other. If interference occurs, waves may attain the critical steepness $1 / 7$ and break $[6,7]$.
The strong easterly winds in the right front quadrant of the typhoon showed considerable uniformity and as a consequence of their continued blowing from the east, the corresponding wind waves were relatively large. For an observer standing initially in the right front quadrant of the typhoon, the wind direction would shift suddenly from southeast to south or southwest as the typhoon center moved northward. Thus in the right rear quadrant new waves were formed, receiving energy from the south or southwest winds. Over the ocean in the right rear quadrant, the seas were then unusually pyramidal, mountainous, and confused. These pyramidal storm waves resulted in considerable damage to the Imperial Japanese 4th Fleet on September 26, 1935.

The wind waves as related to the movement of the typhoon, during the passage of the storm over the main squadron, the torpedo-boat flotilla, the submarine flotilla, the transport ship Tsurumi and the destroyer Hanekaze are given in figure 3 (a reproduction of a chart prepared by the Hydrographic Department). The state of the sea reported according to the sea scale (see below) is also tabulated in table 4 . It is clear that the wave heights were the greatest in the right rear quadant of the

\begin{tabular}{|c|c|c|c|c|}
\hline Time (135th meridian civil time) & $\begin{array}{l}\text { Hanekaze } \\
\text { (in visibil- } \\
\text { ity scale) }\end{array}$ & $\begin{array}{l}\text { Main } \\
\text { squadron } \\
\text { (in } \mathrm{km} \text {.) }\end{array}$ & $\begin{array}{l}\text { Tsurumi } \\
\text { (in visibil- } \\
\text { ity scale) }\end{array}$ & $\begin{array}{l}\text { Torpedo- } \\
\text { boat flotilla } \\
\text { (in } \mathrm{km} \text {.) }\end{array}$ \\
\hline (1) & $\begin{array}{r}6 \\
6 \\
7 \\
10 \\
3 \\
3 \\
3 \\
2 \\
2 \\
2 \\
2 \\
6 \\
6 \\
5 \\
\end{array}$ & $\begin{array}{r}3.3 \\
2.0 \\
1.9 \\
1.8 \\
1.5 \\
1.0 \\
.9 \\
.6 \\
.5 \\
.9 \\
.8 \\
.8 \\
1.8\end{array}$ & $\begin{array}{l}2 \\
2 \\
2 \\
2 \\
1 \\
1 \\
0 \\
0 \\
0 \\
0 \\
0 \\
0 \\
0\end{array}$ & $\begin{array}{l}6.5 \\
8.2 \\
7.8 \\
7.0 \\
4.0 \\
2.7 \\
1.7 \\
1.1 \\
.9 \\
1.1 \\
1.1 \\
1.2 \\
1.2\end{array}$ \\
\hline & $\begin{array}{l}\text { In the left } \\
\text { half of } \\
\text { the ty. } \\
\text { phoon. }\end{array}$ & & \multicolumn{2}{|c|}{$\begin{array}{l}\text { In the right half of the } \\
\text { typhoon. }\end{array}$} \\
\hline
\end{tabular}


TABLE 4.- State of the sea (according to the sea scale) in the typhoon area, Sept. 26,1935

\begin{tabular}{|c|c|c|}
\hline Time (135th meridian clvil time) & $\underset{\text { squadron }}{\text { Main }}$ & $\begin{array}{l}\text { In the } \\
\text { right half } \\
\text { (torpedo- } \\
\text { boat } \\
\text { flotilla) }\end{array}$ \\
\hline 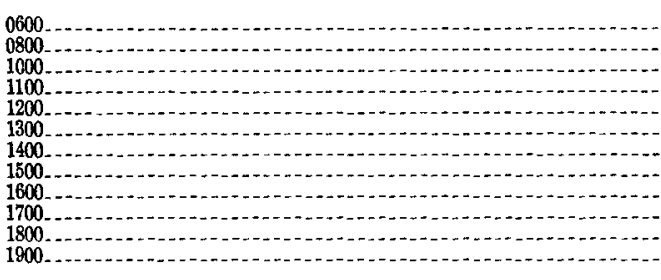 & $\begin{array}{l}4.3 \\
4.3 \\
5.1 \\
5.8 \\
6.7 \\
7.2 \\
7.7 \\
8.3 \\
8.5 \\
8.8 \\
8.3 \\
8.2\end{array}$ & $\begin{array}{l}4.7 \\
4.8 \\
5.6 \\
6.4 \\
7.0 \\
7.9 \\
8.2 \\
8.5 \\
8.4 \\
8.4 \\
8.2 \\
8.0\end{array}$ \\
\hline
\end{tabular}

typhoon. The heights of wind waves as shown in figure 3 may be a little large in view of the values given in table 4. However it is possible that this chart represents extreme values whereas those in table 4 are average heights. The wind forces corresponding to the code figures of the sea scale are indicated below:

\begin{tabular}{|c|c|c|c|}
\hline $\begin{array}{c}\text { Sea scale } \\
\text { code figures }\end{array}$ & General description & $\begin{array}{l}\text { Wind force } \\
\text { equivalent } \\
\text { (in Beaufort } \\
\text { number) }\end{array}$ & $\begin{array}{l}\text { Wave height } \\
\text { equivalent } \\
\text { (in meters) }\end{array}$ \\
\hline 0 & Dead calm & 0 & \\
\hline 1 & Very smooth & 1 & $<0.3$ \\
\hline 2 & Smooth sea & $2-3$ & $0.3-0.6$ \\
\hline 3 & Slight sea & 4 & $0.6-1.0$ \\
\hline 4 & Moderate sea & $\mathbf{5}$ & 1. $0-1.5$ \\
\hline $\mathbf{5}$ & Rather rough sea. & 6 & $1.5-2.5$ \\
\hline 6 & Rough sea....... & 7 & $2.5-4.0$ \\
\hline 7 & High sea & $8-9$ & 4. $0-7.0$ \\
\hline 8 & Very high sea....... & 10 & 7. $0-13.0$ \\
\hline 9 & Phenomenal or precipitous sea & $11-12$ & $>13.0$ \\
\hline
\end{tabular}

The state of the sea is shown more clearly in table 5 which gives measured height, length, velocity, and period for the highest waves. Classical theory on surface waves indicates that velocity $c$, wave length $L$, and period $T$ for deep-water waves which do not involve a bodily transfer of water, are interrelated by the formulas $[6,7]$

$c=\sqrt{g L / 2 \pi}=g T / 2 \pi, L=2 \pi c^{2} / g=g T^{2} / 2 \pi, T=\sqrt{2 \pi L / g}=2 \pi c / g$.

With $c$ in m. sec. ${ }^{-1}, L$ in meters, and $T$ in seconds:

$c=1.25 \sqrt{L}=1.56 T, L=0.641 c^{2}=1.56 T^{2}, T=0.801 \sqrt{L}=0.641 c$.

Thus, if one characteristic quantity is measured the other two can be computed, and if two or three are measured the correctness of the theory as applied to ocean waves can be checked.

Table 6 shows that comparisons of measured and computed values for the Mikuma gave rather unsatisfactory results. This may indicate that the state of the sea as observed by the main squadron was, to some extent, uncertain. Comparisons of measured and computed values for the wavelength and the wave period from the cruiser Nachi on the other hand gave fairly satisfactory results.

After Sverdrup and others [6,7], the steepness defined by the ratio of the wave height, $H$, and the wavelength,

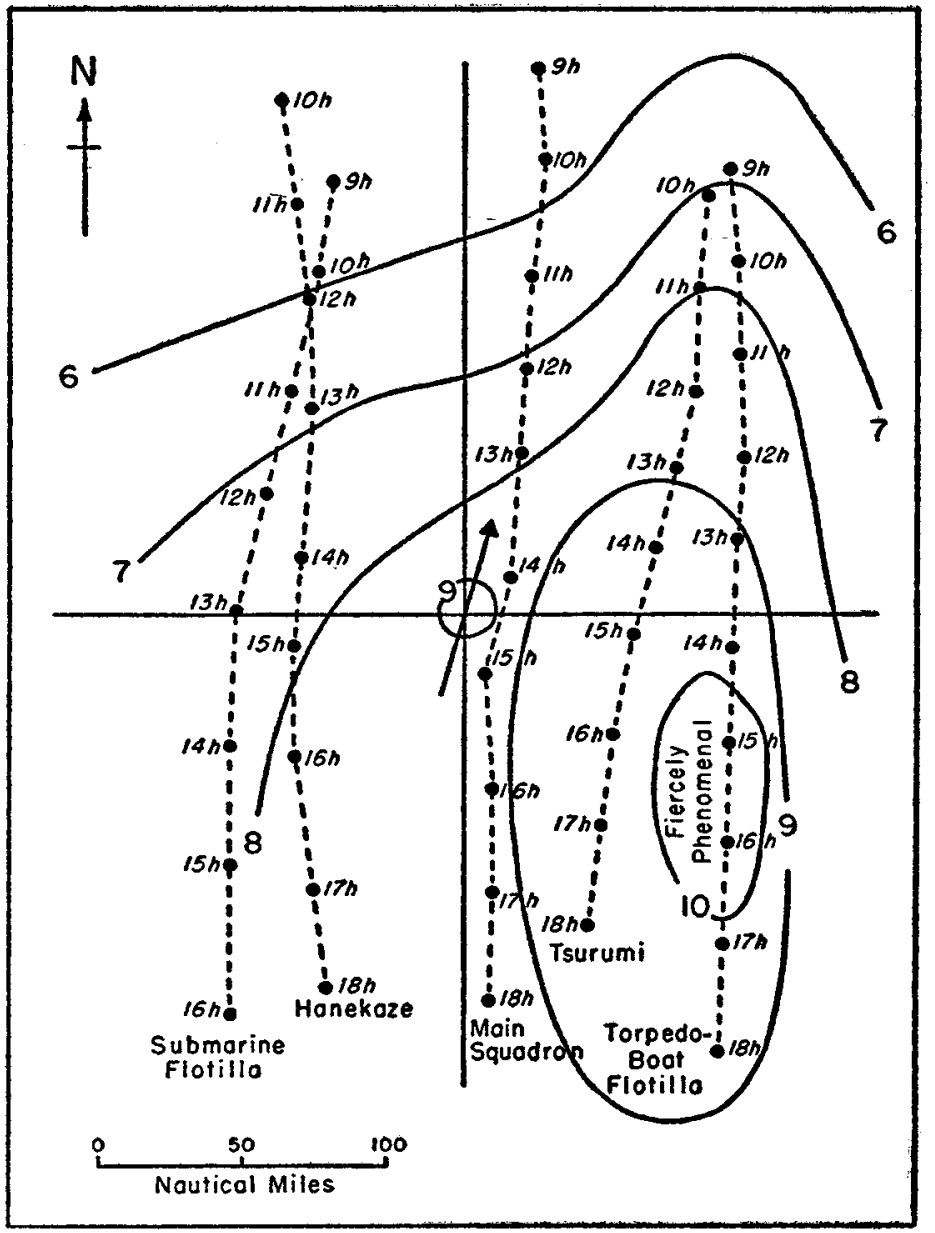

FIGURE 3.-Composite chart showing the state of the sea in the typhoon of September 26, 1935. Intersection of the cross lines represents the center of the typhoon. The arrow through the center indicates the direction of movement of the typhoon. Dots indicate positions of naval units at hourly intervals (JMT). Lines of constant wave heights are drawn for each unit of the sea scale (see scale table in text).

$L$, has the critical value $1 / 7$. Observations from the main squadron confirm that the ratio $H / L$ always remained less than $1 / 7$ except for the uncertain report from the transport ship Susaki.

As is well known, the heights of large waves under stormy conditions are generally overestimated and wave heights above 20 meters are extremely rare. Observations

TABLE 5.-The state of the sea observed by the main squadron in the typhoon area, Sept. 26,1935

\begin{tabular}{|c|c|c|c|c|c|c|}
\hline \multirow{2}{*}{$\begin{array}{l}\text { Name of } \\
\text { ship }\end{array}$} & \multirow{2}{*}{$\begin{array}{c}\text { Time } \\
\text { (135th } \\
\text { meridian } \\
\text { civil } \\
\text { time) }\end{array}$} & \multicolumn{4}{|c|}{ Highest waves } & \multirow{2}{*}{$\begin{array}{c}\text { Steepness } \\
H / L \\
\text { (com- } \\
\text { puted) }\end{array}$} \\
\hline & & $\begin{array}{l}\text { Hoight } H \\
\text { (meters) }\end{array}$ & $\begin{array}{l}\text { Wave length } L \\
\text { (meters) }\end{array}$ & $\begin{array}{c}\text { Wave } \\
\text { velocity c } \\
\text { (m/sec) }\end{array}$ & $\begin{array}{l}\text { Period } T \\
\text { (second) }\end{array}$ & \\
\hline \multirow{6}{*}{$\begin{array}{l}\text { Hosho } \\
\text { Mikuma } \\
\text { Hosho } \\
\text { Hoshó } \\
\text { Haguro } \\
\text { Mikuma } \\
\text { Amagiri } \\
\text { Asakaze... }\end{array}$} & 1215 & 10 & & & & \\
\hline & 1250 & 8 & 180 & 14.3 & 13.0 & $1 / 25$ \\
\hline & 1420 & 18 & & & & $\ldots . . . . .$. \\
\hline & $\begin{array}{l}1418 \\
1445\end{array}$ & 15 & A bout $\begin{array}{r}350 \\
200\end{array}$ & 14,3 & 13,3 & $1 / 23$ \\
\hline & 1458 & $\begin{array}{r}25 \\
-25\end{array}$ & $\begin{array}{r}300 \\
\end{array}$ & - & - & $1 / 12$ \\
\hline & & & (estimated) & & & $1 / 13 \sim 1 / 20$ \\
\hline \multirow{2}{*}{$\begin{array}{l}\text { Nachi } \\
\text { Tsurumi } \\
\text { Naka }\end{array}$} & $\begin{array}{l}1500 \\
1500\end{array}$ & \multirow{4}{*}{$\begin{array}{r}13 \sim 14 \\
>10 \\
14 \\
\text { (pyramidal) } \\
20 \sim 30 \\
13 \sim 14\end{array}$} & A bout 200 & 9 & 9 & $\begin{array}{r}1 / 9 \\
1 / 20\end{array}$ \\
\hline & 1522 & & 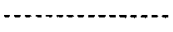 & & & \\
\hline \multirow{2}{*}{$\begin{array}{l}\text { Susaki...... } \\
\text { Nacht }\end{array}$} & 1540 & & 150 & & & \multirow{2}{*}{$\begin{array}{r}1 / 8 \sim 1 / 5 \\
1 / 9\end{array}$} \\
\hline & 1550 & & About 120 & About 8 & About 9 & \\
\hline
\end{tabular}


from the main squadron confirm that the wave height, $H$, generally remained less than 20 meters except for the uncertain report from the transport ship Susaki.

Swell in relation to the position and direction of movement of the center during the passage of this typhoon is

\begin{tabular}{|c|c|c|c|c|c|c|c|c|c|}
\hline \multirow{3}{*}{$\begin{array}{c}\text { Name of } \\
\text { ship }\end{array}$} & \multicolumn{3}{|c|}{$\begin{array}{l}\text { Wave velocity } c, \\
\text { m. sec.-1 }\end{array}$} & \multicolumn{3}{|c|}{ Wave length $L, \mathrm{~m}$. } & \multicolumn{3}{|c|}{ Wave period $T$, sec. } \\
\hline & \multirow[b]{2}{*}{$\begin{array}{l}\text { 莒 } \\
\text { 总 } \\
\text { 。 }\end{array}$} & \multicolumn{2}{|c|}{ Computed } & \multirow[b]{2}{*}{$\begin{array}{l}\text { : } \\
\text { : } \\
\text { : } \\
\text { : } \\
0\end{array}$} & \multicolumn{2}{|c|}{$\begin{array}{l}\text { Computed } \\
\text { from- }\end{array}$} & \multirow[b]{2}{*}{ 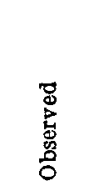 } & \multicolumn{2}{|c|}{$\begin{array}{l}\text { Computed } \\
\text { from- }\end{array}$} \\
\hline & & 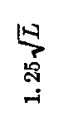 & $\begin{array}{l}\text { E. } \\
\text { \&o } \\
-1\end{array}$ & & $\begin{array}{l}\overline{0} \\
\overline{0} \\
0\end{array}$ & 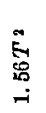 & & 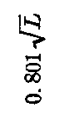 & $\begin{array}{l}\vec{F} \\
\stackrel{0}{0} \\
\end{array}$ \\
\hline$M i^{i k} m^{u}$ & 14.3 & 16.8 & 20.3 & 180 & 131 & 264 & 13. 0 & 10.7 & 9.2 \\
\hline$M i k u m a$ & 14. 3 & 17.7 & 20.7 & 200 & 131 & 276 & 13.3 & 11.3 & 9.2 \\
\hline Nachi $(1500$ & 9 & 13. 7 & 14.0 & 120 & 52 & 126 & 9 & 8.8 & 5.8 \\
\hline $\begin{array}{l}\text { Nachi } \\
\text { JMT). }\end{array}$ & About 8 & 13. 7 & 14,0 & About 120 & 41 & 126 & A bout $\theta$ & 8.8 & 5.1 \\
\hline
\end{tabular}

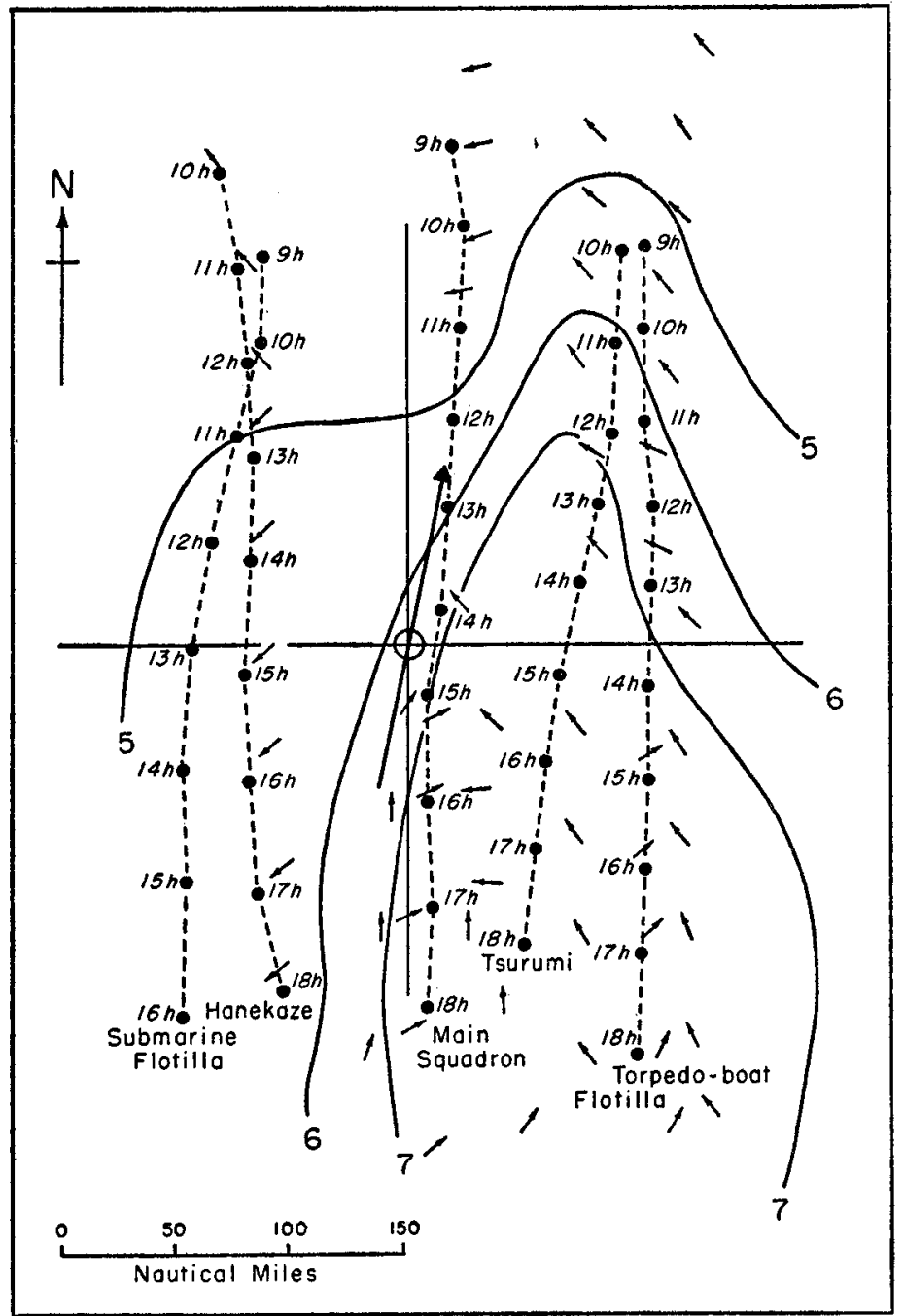

Fiodre 4.-Composite chart showing swell in the typhoon of September 26, 1935. Intersection of cross lines represents the center of the typhoon. The heavy arrow through the center indicates the direction of movement of the typhoon. Dots indicate positions of naval units at houriy intervals (JMT). Small arrows show the directions of swell. Lines of constant swell oharacter are drawn for each unit of the swell scale. charted in figure 4, which is also a reproduction of a chart prepared by the Hydrographic Department. The swell of greatest intensity also occurred in the right rear quadrant.

The state of the pyramidal sea in the right rear quadrant (1520 JMT) was photographed by Lieut. G. Matsuura looking to the windward on board the Cruiser Nachi. Because the quality of the photograph is too poor for reproduction, the behavior is illustrated schematically in figure 5. Tannehill [8] showed the deviation of wind to the left of the swell in the Northern Hemisphere; that is, the observer standing with his back to the wind would find the swell moving off to the right. Figure 5 shows clearly the opposite case; that is, the observer standing with his face to the southwest strong wind found the swell moving off to his right within this limited area; i. e., in the right rear quadrant.

The rolling and pitching of ships are of course a function of the winds, the state of the sea, and the characteristics of ships. They can hardly be analyzed therefore in a simple manner. The maximum amplitudes of the rolling, in degrees, are tabulated in table 7 for reference. These angles are the total angle of roll from port to starboard.

Figure 6 portrays the path of the typhoon center during the critical period of 1100 to 1700 JMT of September 26, and the trajectory traversed by the main squadron during the period of $2000 \mathrm{JMT}$ of the 25th to $1800 \mathrm{JMT}$ of the 26th. The thin full lines are lines of constant sea depth

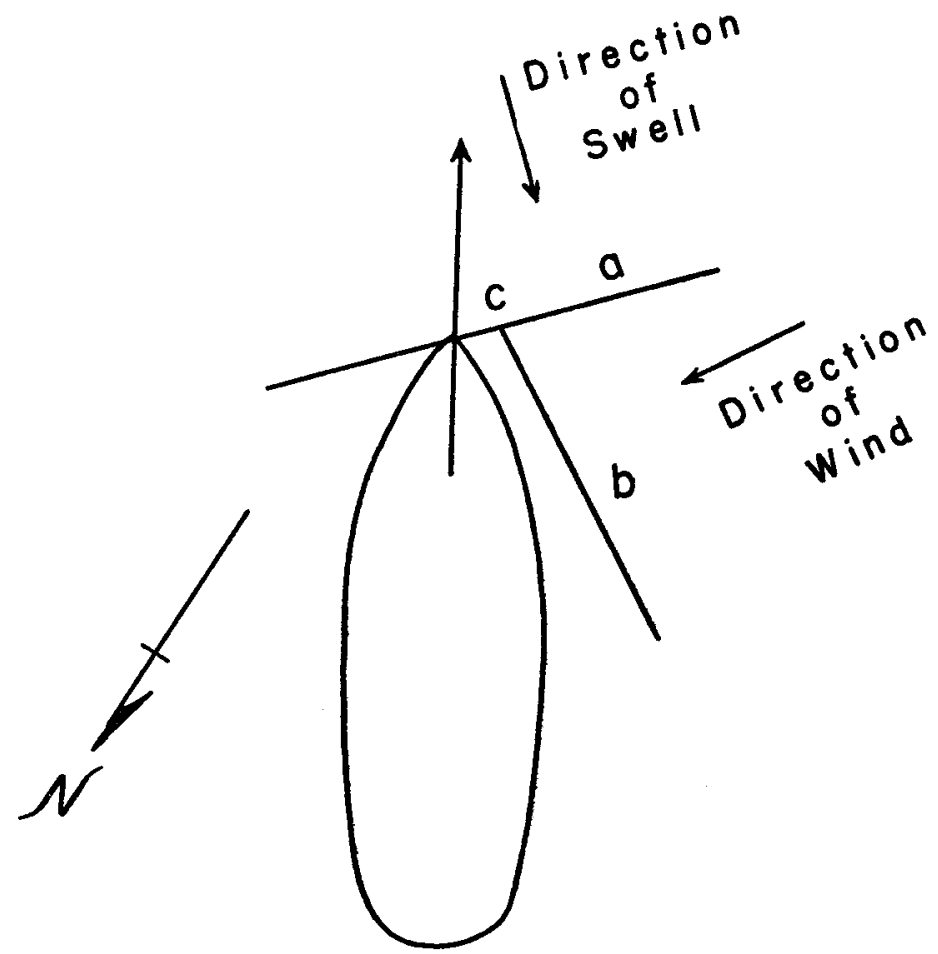

FIGURE 5.-Schematic illustration of the behavior of the sea in the right rear quadrant (1520 JMT) of the typhoon of September 26, 1935. Based on photographs by Lieut. $G$. Matsuura, looking to the windward on board the cruiser Nachi. The direction of movement of the cruiser was 15 on the 36-point direction scale. \& indicates the wave front of swells from the southeast; $b$, the wave front of wind waves under the infuence of wind of speed $27 \mathrm{~m}$. sec.-1 and direction 21 ; c, pyramidal waves. Note the deviation of the wind to the right of the swell, a marked exception to Tannehill's rule [8]. 
TABLE 7.-Greatest amplitude of the rolling of the ships from port to starboard in degrees, Sept. 26, 1985

\begin{tabular}{|c|c|c|c|c|c|c|c|c|c|c|c|c|c|c|}
\hline \multirow[b]{2}{*}{$\begin{array}{c}\operatorname{Tim} \theta \\
\text { (183th meridian civil time) }\end{array}$} & \multirow{2}{*}{$\begin{array}{l}\text { In the left } \\
\text { half of the } \\
\text { typhoon } \\
\text { Hanekaze }\end{array}$} & \multirow{2}{*}{$\begin{array}{l}\text { Ashigara } \\
\text { Mydko } \\
\text { Nachi } \\
\text { Haguro }\end{array}$} & \multirow[b]{2}{*}{$\begin{array}{l}\text { Mogami } \\
\text { Mikuma }\end{array}$} & \multirow{2}{*}{$\begin{array}{c}\text { Kitakami } \\
\text { Ooi } \\
\text { Kiso } \\
\text { Sendai }\end{array}$} & \multirow[b]{2}{*}{ Ryazyo } & \multirow[b]{2}{*}{ Ho:yo } & \multirow[b]{2}{*}{ Tenryu } & \multirow[b]{2}{*}{ Taigei } & \multirow[b]{2}{*}{ Kamui } & \multicolumn{5}{|c|}{ In the right half of the typhoon } \\
\hline & & & & & & & & & & Trurumi & $\begin{array}{l}\text { Kinu } \\
\text { Naka }\end{array}$ & $\begin{array}{l}\text { Extra } \\
\text { class de- } \\
\text { stroyer }\end{array}$ & $\begin{array}{c}T s u k i \\
\text { class de- } \\
\text { stroyer }\end{array}$ & $\begin{array}{c}\text { Kaze } \\
\text { class da. } \\
\text { stroyer }\end{array}$ \\
\hline $\begin{array}{l}0600 \\
0700 \\
0800 \\
0900 \\
1000 \\
1100 \\
1200 \\
1300 \\
1400 \\
1500 \\
1600 \\
1700 \\
1800\end{array}$ & \begin{tabular}{r|}
6 \\
6 \\
6 \\
8 \\
12 \\
10 \\
22 \\
27 \\
30 \\
38 \\
44 \\
50 \\
49
\end{tabular} & $\begin{array}{r}8 \\
8 \\
8 \\
8 \\
8 \\
10 \\
9 \\
15 \\
22 \\
23 \\
22 \\
22 \\
19\end{array}$ & $\begin{array}{r}8 \\
8 \\
9 \\
9 \\
10 \\
11 \\
15 \\
18 \\
24 \\
24 \\
25 \\
26 \\
26\end{array}$ & \begin{tabular}{r|}
9 \\
10 \\
11 \\
12 \\
14 \\
13 \\
13 \\
18 \\
28 \\
25 \\
30 \\
31 \\
24
\end{tabular} & $\begin{array}{l}15 \\
13 \\
18 \\
20 \\
20 \\
20 \\
13 \\
13 \\
21 \\
18 \\
19 \\
18 \\
28\end{array}$ & $\begin{array}{l}11 \\
11 \\
10 \\
11 \\
10 \\
10 \\
26 \\
15 \\
31 \\
41 \\
27 \\
26 \\
15\end{array}$ & $\begin{array}{l}25 \\
30 \\
28 \\
24 \\
33 \\
25 \\
20 \\
45 \\
65 \\
68 \\
37 \\
32 \\
30\end{array}$ & $\begin{array}{l}7 \\
7 \\
6.5 \\
7 \\
25 \\
35 \\
45 \\
60 \\
75 \\
100 \\
73 \\
55 \\
55\end{array}$ & $\begin{array}{l}57 \\
32 \\
32 \\
20 \\
27 \\
23 \\
31 \\
24 \\
48 \\
58 \\
53 \\
48 \\
45\end{array}$ & $\begin{array}{l}14 \\
13 \\
15 \\
16 \\
16 \\
18 \\
20 \\
32 \\
24 \\
30 \\
34 \\
34 \\
30\end{array}$ & $\begin{array}{l}16 \\
14 \\
12 \\
14 \\
23 \\
29 \\
21 \\
44 \\
60 \\
47 \\
42 \\
52 \\
60\end{array}$ & $\begin{array}{r}16 \\
18 \\
20 \\
22 \\
24 \\
27 \\
34 \\
53 \\
54 \\
67 \\
68 \\
69 \\
65 \\
2\end{array}$ & $\begin{array}{l}16 \\
17 \\
19 \\
17 \\
22 \\
29 \\
39 \\
56 \\
64 \\
75 \\
69 \\
68 \\
64\end{array}$ & $\begin{array}{l}18 \\
18 \\
23 \\
25 \\
27 \\
35 \\
53 \\
53 \\
58 \\
67 \\
69 \\
70 \\
62\end{array}$ \\
\hline
\end{tabular}

drawn for each 1,000 meters. They indicate that wind, waves, and swell do have the characteristics of the surface waves.

In table 8 are listed certain ships which have been frequently mentioned in this paper.

TABLE 8.- List of ships quoted in the present paper (from KaigunYôran, 1985)

\begin{tabular}{|c|c|c|}
\hline Name & Type of ships & $\begin{array}{l}\text { Tonnage } \\
\text { (displace- } \\
\text { ment) }\end{array}$ \\
\hline Amapiri...- & \multirow{18}{*}{ 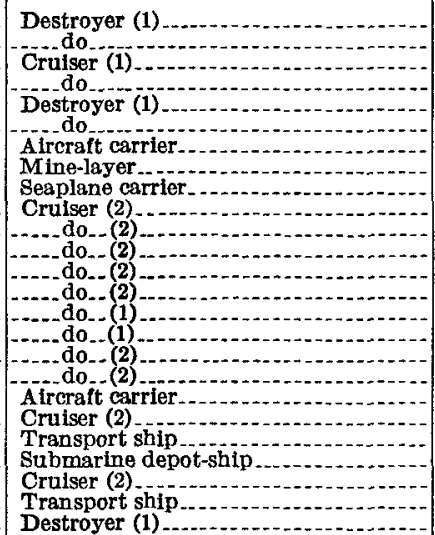 } & \multirow{18}{*}{$\begin{array}{r}1,700 \\
1,270 \\
10,000 \\
10,000 \\
1,215 \\
1,700 \\
7,470 \\
1,970 \\
17,000 \\
5,170 \\
5,100 \\
5,100 \\
8,500 \\
8,500 \\
10,000 \\
10,000 \\
5,195 \\
5,100 \\
7,100 \\
5,185 \\
8,800 \\
10,000 \\
3,230 \\
14,050 \\
1,700\end{array}$} \\
\hline shigara. & & \\
\hline Hapuro & & \\
\hline Hanekaze- & & \\
\hline 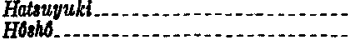 & & \\
\hline Kamuitima.- & & \\
\hline & & \\
\hline Kiso & & \\
\hline $\begin{array}{l}\text { Küakami-..... } \\
\text { Makuma...... }\end{array}$ & & \\
\hline Mogami...... & & \\
\hline Myoud ...... & & \\
\hline & & \\
\hline & & \\
\hline Ryarzyo. & & \\
\hline & & \\
\hline Taiget & & \\
\hline & & \\
\hline Yhurumi & & \\
\hline \multirow{2}{*}{\multicolumn{2}{|c|}{$\begin{array}{l}\text { Destroyer: } \\
\text { Extra class... } \\
\text { Tsuki class.. }\end{array}$}} & \multirow{3}{*}{$\begin{array}{l}1,700 \\
1,315 \\
1,270\end{array}$} \\
\hline & & \\
\hline & & \\
\hline
\end{tabular}

\section{REFERENCES}

1. Hydrographic Department, Imperial Japanese Navy, Investigations of the Typhoon of September 26, 1985, Whose Center Traversed Over the Sea Where the RED 4th Fleet, Imperial Japanese Navy Was Maneuvering. 1937,19 pp. +XIV plates. (In Japanese)

2. Meteorological Department, Imperial Japanese Navy, Reference Data on Typhoons, 1944, 29 pp.+XX plates. (In Japanese)

3. Central Meteorological Observatory, Tokyo, Geophysical Review (Kishó Yôran) September 1935, pp. 766-778.

4. Sir Napier Shaw and R. G. K. Lempfert, "The Life History of Surface Air Currents," $M .0 .174$, published by the authority of the Meteorological Committee, London, 1906.

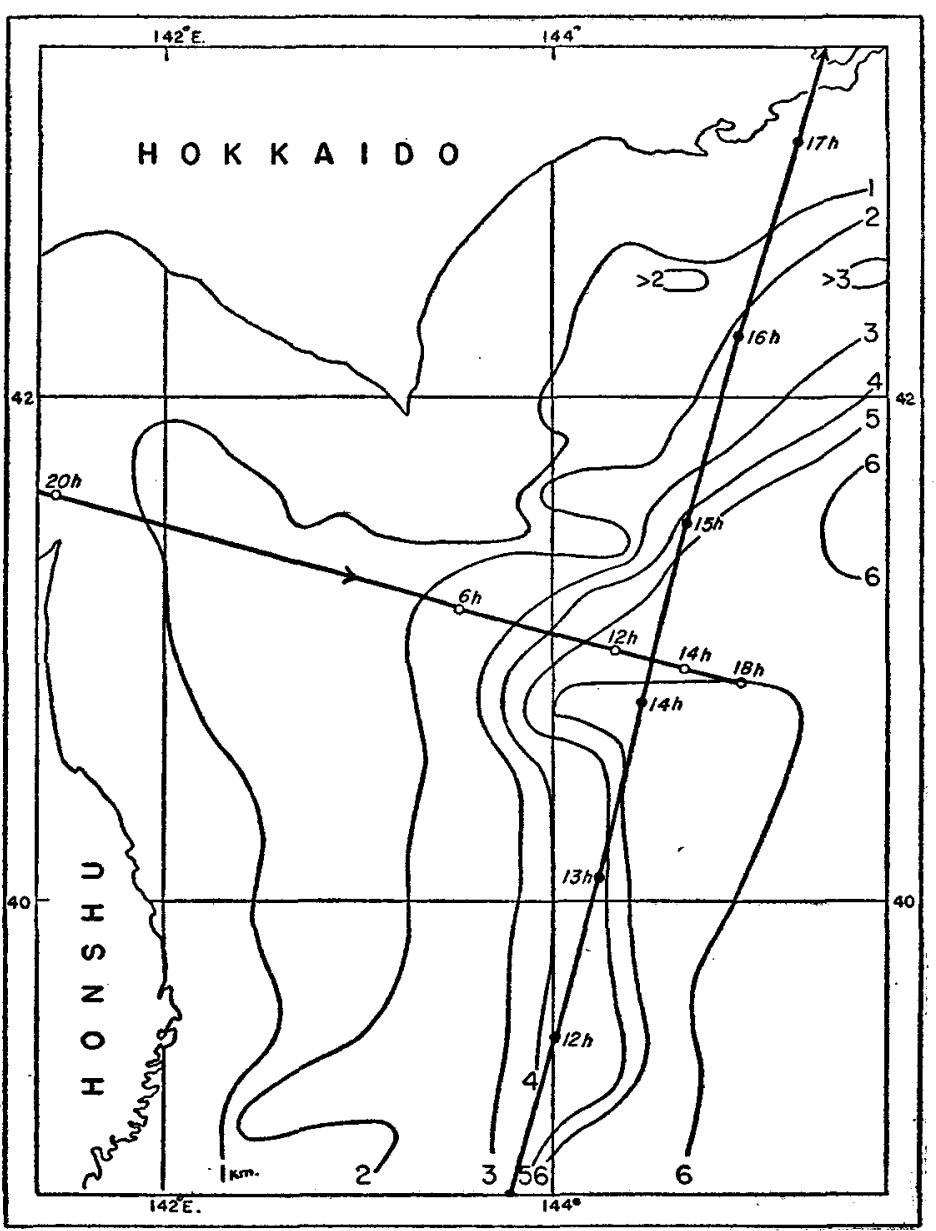

Fif URe 6.-Path of the typhoon center during the critical period from 1100 to 1700 JMT September 26,1935 . Dots indicate hourly positions (JMT) of the center, and circles the positions of the main naval squadron from $2000 \mathrm{JMT}$, September 25 to $1800 \mathrm{JMT}$, September 26. Isolines of constant sea depth are drawn for each 1000 meters.

Sir Napier Shaw, Forecasting Weather, Constable \& Co., London, 1911, p. 212, fig. 96.

5. Isaac M. Cline, Tropical Cyclones, MacMillan Co., New York, 1926, $301 \mathrm{pp}$.

6. H. U. Sverdrup, Martin W. Johnson, and Richard H. Fleming, The Oceans, Prentice-Hall, New York, $1942,1087 \mathrm{pp}$.

7. H. U. Sverdrup, Oceanography for Meteorologists, Prentice-Hall, New York, 1942, 246 pp.

8. Ivan R. Tannehill, Hurricanes, Princeton Univ. Press, Princeton, 1938, p. 91. 